\title{
Feeding behaviors of a sea urchin, Mesocentrotus nudus, on six common seaweeds from the east coast of Korea
}

\author{
Kwon Mo Yang ${ }^{1}$, Byung Hee Jeon ${ }^{2}$, Hyung Geun Kim ${ }^{3}$ and Jeong Ha Kim ${ }^{1, *}$ \\ ${ }^{1}$ Department of Biological Sciences, Sungkyunkwan University, Suwon 16419, Korea \\ ${ }^{2}$ Ecological Restoration Division, Korea Fisheries Resources Agency, Busan 46041, Korea \\ ${ }^{3}$ Department of Marine Bioscience, Gangneung-Wonju National University, Gangneung 25457, Korea
}

The sea urchin, Mesocentrotus nudus, is widely distributed in North West Pacific regions. It has a substantial impact on macroalgal communities as a generalist herbivore. This study examined various aspects of its feeding ecology, including algal preference, foraging behaviors, and possible effects of past feeding history on its algal preference. We used six common algal species (Ulva australis, Undaria pinnatifida, Sargassum confusum, Dictyopteris divaricata, Grateloupia elliptica, and Grateloupia angusta) from the east coast of Korea as food choice in a series of indoor aquarium experiments. The first choice of starved M. nudus was exclusively U. pinnatifida, followed by G. elliptica and S. confusum. Unlike large urchins, small urchins equally preferred U. pinnatifida and G. elliptica. On the other hand, Undaria-fed urchins preferred to feed only G. elliptica, although its preference slightly differed over time. We then grouped sea urchins into three categories (starved, Undaria-fed, mixed species-fed) to observe 12-days feeding preference as well as early foraging movements. Foraging behaviors of the three groups were distinctively different, although they could not completely reflect the actual consumption. For example, U. australis was highly attractive, but rarely eaten. Undaria-fed urchins seemed to stay with only $S$. confusum and $U$. australis. This study demonstrates that $M$. nudus shows high flexibility in food preference depending on past feeding history and body size. Its foraging behaviors are also affected by past feeding conditions, exhibiting active chemoreceptive movements.

Key Words: feeding preference; foraging behavior; Mesocentrotus nudus; past feeding history; sea urchin; Undaria pinnatifida

\section{INTRODUCTION}

In marine benthic ecosystems, herbivores have a substantial effect on macroalgal community structure through their preferential feeding behavior (Paine and Vadas 1969, Worm et al. 2002, Hillebrand and Cardinale 2004). The palatability of algae and feeding preference of herbivores can lead to complex interactions between chemical or structural defense mechanisms of plants and absorption efficiency or availability of herbivores (Vadas
1977, Jormalainen et al. 2008). Therefore, herbivore feeding behavior and food availability fundamentally affect the food chain and energy flow in marine ecosystems (Huntly 1991, Burkepile and Hay 2006).

High densities of sea urchins as major mesoherbivores are a major cause for barren states in subtidal habitats (Elner and Vadas 1990, Dayton et al. 1992, Pearse 2006, Agnetta et al. 2013). Particularly, sea urchins in the fam-
(9) $\$$ This is an Open Access article distributed under the terms of the Creative Commons Attribution Non-Commercial License (http://creativecommons.org/licenses/by-nc/3.0/) which permits unrestricted non-commercial use, distribution, and reproduction in any medium, provided the original work is properly cited.
Received January 9, 2021, Accepted March 5, 2021

* Corresponding Author

E-mail: jhkbio@skku.edu

Tel: +82-31-290-7009, Fax: +82-31-290-7015 
ily of Strongylocentrotidae are ecologically important in many coastal areas around the world because their distribution largely overlaps with kelp deforested areas (Pearse 2006, Filbee-Dexter and Scheibling 2014, Krumhansl et al. 2016, Filbee-Dexter and Scheibling 2017). In addition, their feeding preference can determine the community structure (Palacín et al. 1998, Steneck 2013), the spatial and temporal distribution of food species, and their availability in natural habitats (Vadas 1977, Harrold and Reed 1985, Agnetta et al. 2013). Food preference by sea urchins reflects their nutrient needs for somatic / gonadal growth regarding their body size (Larson et al. 1980, Lemire and Himmelman 1996, Seymour et al. 2013, Westbrook et al. 2015). Therefore, algal preference can be affected or altered by an urchin's past feeding history (Vadas 1977, Lyons and Scheibling 2007). Flexibility in food choice has been examined in relation to maximizing caloric intake as an energy or nutrient optimization strategy (Vadas 1977, Lemire and Himmelman 1996). In addition, sea urchins move using their spines and tube feet and have a chemoreceptive ability to detect food sources around them (Mann et al. 1984, Lemire and Himmelman 1996, Lauzon-Guay and Scheibling 2008). This may suggest that sea urchins have selective foraging behaviors to increase their fitness and that their changed preference can affect the overall community structure.

The sea urchin, Mesocentrotus nudus (previously known Strongylocentrotus nudus), used in this study is widely distributed in the Northwest Pacific Ocean, including regions from Dalian, China to Primorsky Krai, Russia (Agatsuma 2001, Yurchenko and Reunov 2004). This species generally prefers brown algae such as Saccharina longissima, S. japonica, and Undaria pinnatifida (Machiguchi et al. 1994, Kawamata 1997, Kim et al. 2007). Unlike other widely studied Strongylocentrotidae sea urchins, little is known about the feeding behavior of M. nudus. This information could be particularly useful for understanding mechanistic changes of macroalgal assemblages where urchin density is a key factor such as urchin barrens in the Northwest Pacific and other regions.

In this study, we determined various feeding habits of $M$. nudus, including food preference and foraging behavior comparing their foraging movement with actual consumption rate. We also examined if preference could change depending on urchin's body size and past feeding history. We discussed the feeding preference and foraging behavior of $M$. nudus with regard to optimal foraging theory.

\section{MATERIALS AND METHODS}

\section{Sampling of sea urchins and algal species}

The following six foliose algal species were used to determine the food preference of M. nudus: Ulva australis, Undaria pinnatifida, Sargassum confusum, Dictyopteris divaricata, Grateloupia elliptica, and Grateloupia angusta. These species commonly inhabit the central east coast of Korea (Sohn et al. 2007, Shin et al. 2008, Kim et al. 2014). They were selected as representative species for this region. Sea urchins and algae were collected by SCUBA from the subtidal zone (about 8-10 $\mathrm{m}$ depth) of the coast near Gangneung City, Gangwon Province,

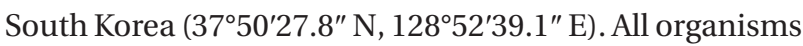
were kept in flowing seawater tanks for seven days to acclimate before they were used for experiments (see also Hernández et al. 2004).

\section{Experimental designs and setting}

This study was conducted in June and July of 2014 at the Marine Biology Center for Research and Education at Gangneung-Wonju National University located in Gangneung City. The aquaria $(50 \times 70 \times 50 \mathrm{~cm})$ used for feeding experiments were supplied with continuous flowing seawater at temperature of $17-20^{\circ} \mathrm{C}$ with turnover rate of $7 \mathrm{~L}$ per minute, which was pre-filtered from the nearby coast. Each experiment used branches or whole plants for each species except for large brown algae (S. confusum and $U$. pinnatifida), for which branches with blades and stipes (excluding their holdfasts and reproductive parts) were used because whole plants were too big to be used in experiments. Blotted wet weight was measured for all algae after gently shaking off excess water. Algae were tied on stainless-steel mesh and placed at the bottom of each aquarium with a plastic cable tie. Experimental aquaria contained sea urchins with six algal species. Control aquaria without sea urchins were used to measure autogenic change of algal biomass.

Experiment 1. This experiment tested primary feeding preferences of M. nudus. A total of 20 sea urchins (ten large urchins with mean test diameter of $75.3 \pm 1.4 \mathrm{~mm}$ and weight of $101.23 \pm 9.28 \mathrm{~g}$ and 10 small urchins with mean test diameter of $43.6 \pm 1.1 \mathrm{~mm}$ and weight of 34.01 $\pm 2.56 \mathrm{~g}$ ) were starved for 15 days (see Chang et al. 1999, James and Siikavuopio 2012), after which two individuals were placed in each of five aquaria. Sea urchins were allowed to freely feed on these six algal species (starting mean weight: U.australis, $13.83 \mathrm{~g}$; U. pinnatifida, 
157.31 g; S. confusum, 114.84 g; D. divaricata, 8.99 g; G. elliptica, $49.7 \mathrm{~g}$; and G. angusta, $5.78 \mathrm{~g}$, blotted wet weight) for 12 days. Remnants of algal thalli (no species were completely eaten) were then re-weighed and compared to those in the five control aquaria to calculate the consumption rate.

Experiment 2. This experiment examined possible changes in urchin's preference as a result of past feeding history. Because $U$. pinnatifida was the most preferred species from Experiment 1, ten new sea urchins were fed with $U$. pinnatifida only for 15 days prior to this experiment. Two sea urchins were placed in each of five experimental aquaria with five control aquaria. Physical conditions of the aquaria and days spent for the experiment were the same as in Experiment 1 except that mixed sizes (one large and one small) of urchins (mean test diameter of $61.2 \pm 1.9 \mathrm{~mm}$ and weight of $63.96 \pm 7.5 \mathrm{~g}$ ) were used. The consumption rate was measured twice (early 6 days and later 6 days) to see possible changes in preference over time (starting mean weight: $U$. australis, $16.36 \mathrm{~g} ; U$. pinnatifida, 127.62 g; S. confusum, 73.74 g; D. divaricata, 13.92 g; G. elliptica, 48.56 g; and G. angusta, 6.78 g, blotted wet weight).

Experiment 3. Foraging movement (or behavioral choice) of M. nudus was observed using urchins with various past feeding conditions. Sea urchins (test diameter of $59.5 \pm 1.9 \mathrm{~mm}$, mean weight of $69.40 \pm 7.1 \mathrm{~g}$ ) were divided into three different past feeding conditions: (1) a state of starvation (starved group), (2) a state of being fed with only U. pinnatifida (Undaria-fed group), and (3) a state of being freely fed with all six algal species (mixed species-fed group). Fifteen days of such past feeding conditions were maintained prior to initiation of the experiment. Nine randomly selected individuals from each past feeding trial (total 27 individuals) were placed at the center of three aquaria of each feeding condition (three individuals for each aquarium, total nine aquaria). Six algal species were placed around the corner of the aquarium, allowing urchins to freely approach any of six choices. To measure and assess urchin's foraging behavior, we counted the number of sea urchins approaching (within $5 \mathrm{~cm}$ excluding spine length) or touching any food choice every $30 \mathrm{~min}$. Since M. nudus showed more active foraging behavior at night time (Hayakawa and Kittaka 1984), observation and counting were conducted for the first 4 $\mathrm{h}$ at night (from 12:00 am to 4:00 am). After this period, we let sea urchins freely feed on algae for 10 days. The actual consumption rate was calculated in comparison with the control group. All urchins were never used more than once throughout the series of experiment.

\section{Data analysis}

Changes in wet weight of algal food species in the experimental aquaria and the control aquaria were used to calculate the actual consumption rate using the following equation (see Molis et al. 2006, 2008):

Actual consumption per day $=\left\{\mathrm{F}_{\mathrm{b}} \times\left(\mathrm{C}_{\mathrm{e}} \times \mathrm{C}_{\mathrm{b}}{ }^{-1}\right)-\mathrm{F}_{\mathrm{e}}\right\} /(\mathrm{D} \times \mathrm{N})$

$\left(\mathrm{F}_{\mathrm{b}}\right.$ : treatment wet weight at the beginning of experiment; $\mathrm{C}_{\mathrm{b}}$ : control wet weight at the beginning; $\mathrm{F}_{\mathrm{e}}$ : treatment wet weight at the end of experiment; $\mathrm{C}_{\mathrm{e}}$ : control wet weight at the end; $\mathrm{D}$ : days of the experiment; $\mathrm{N}$ : individual number of urchins)

Analysis of variance (ANOVA) was performed to compare consumption rates between experimental groups. Before using data for ANOVA, all data were checked for normality using Kolmogorov-Smirnov test and homogeneity of variance using Levene's test. Data were then log $(\mathrm{x}+1)$ transformed to convert every dependent variable to a positive value because some calculated actual consumption rates had negative values (assumed that autogenic growth weight was higher than the amount of consumption). For the primary preference test (Experiment 1), one-way ANOVA was performed. Significance levels were marked on graphs. For effects of different feeding conditions on preference (Experiments 2 and 3), we used two-way ANOVA (Feeding $\times$ Algae). A repeated measures ANOVA was used to detect a possible preference change between early and later periods of the Undaria-fed group in Experiment 2. All statistical analyses were performed using SPSS version 21.0 (IBM Corp., Armonk, NY, USA).

\section{RESULTS}

\section{Primary feeding preference and difference be- tween large and small group}

Regarding the primary feeding preference of M. nudus, the most preferred food was $U$. pinnatifida $\left(2.68 \mathrm{~g} \mathrm{~d}^{-1}\right)$, followed by G. elliptica (1.51 $\left.\mathrm{g} \mathrm{d}^{-1}\right)$ and Sargassum confusum (1.31 $\mathrm{g} \mathrm{d}^{-1}$ ) (Fig. 1). For the other three species, $U$. australis $\left(0.25 \mathrm{~g} \mathrm{~d}^{-1}\right)$, D. divaricata $\left(0.13 \mathrm{~g} \mathrm{~d}^{-1}\right)$, and G. angusta $\left(0.04 \mathrm{~g} \mathrm{~d}^{-1}\right)$ were consumed in very little amount. Thus, they were identified as unfavorable foods. For sea urchins with different sizes (large vs. small), there was a difference in feeding preference order between them $(\mathrm{p}=0.012)$ (Fig. 2). The most preferred food by large urchins was exclusively $U$. pinnatifida $\left(3.49 \mathrm{~g} \mathrm{~d}^{-1}\right)$, while $G$. 


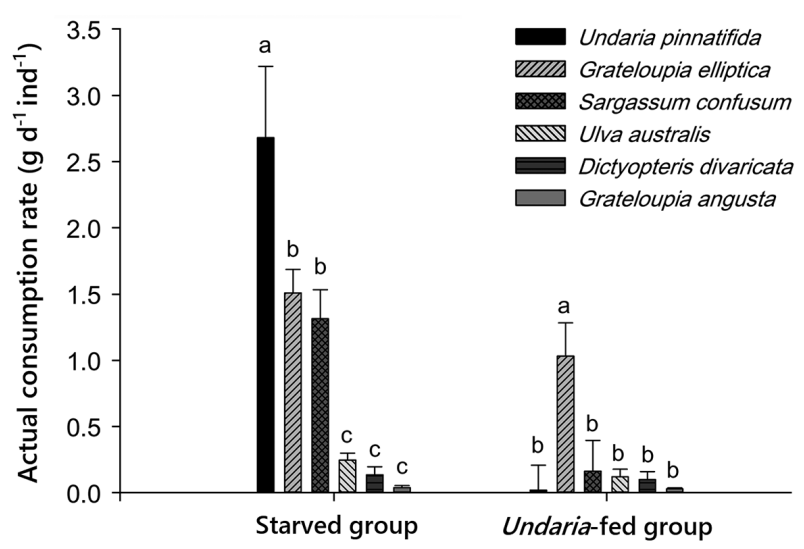

Fig. 1. Actual consumption rate of starved group and Undaria-fed group in Experiments 1 and 2. Each bar indicates mean \pm standard error and the alphabets above the bars indicate different groups at $95 \%$ significance.

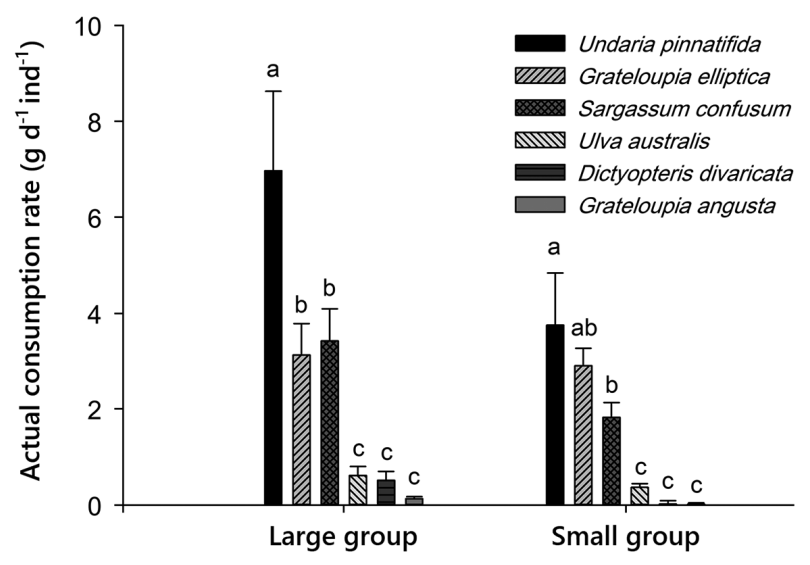

Fig. 2. Actual consumption rate of large and small group in starved group of Mesocentrotus nudus in Experiment 1. Each bar is mean \pm standard error and the alphabets indicate different groups at $95 \%$ significance.

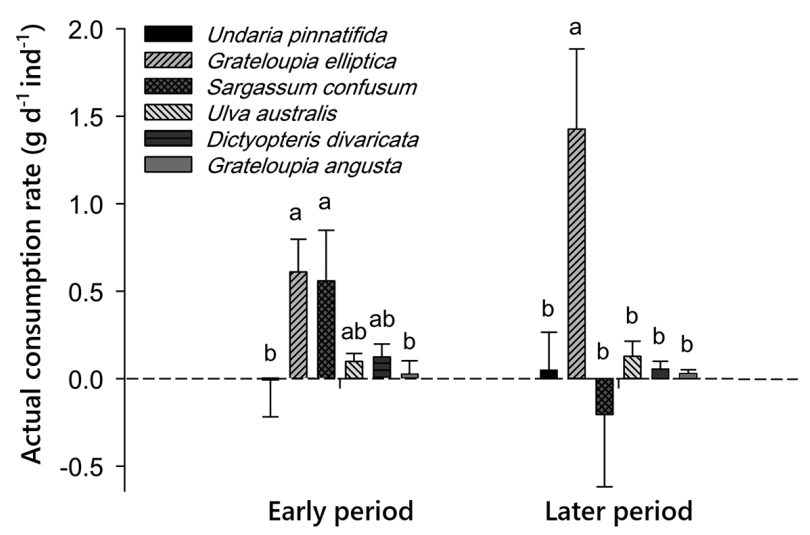

Fig. 3. Actual consumption rate of the early and later period in Undaria-fed group of Mesocentrotus nudus in Experiment 2. Each bar is mean \pm standard error and the alphabets indicate different groups at $95 \%$ significance. elliptica $\left(1.45 \mathrm{~g} \mathrm{~d}^{-1}\right)$ and $U$. pinnatifida $\left(1.88 \mathrm{~g} \mathrm{~d}^{-1}\right)$ were equally preferred by small urchins (Fig. 2). S. confusum was also consumed at a similar amount as G. elliptica but not much as $U$. pinnatifida by both large and small group. However, U. australis, D. divaricata, and G. angusta were consistently not preferred by either large or small urchins.

\section{Preference changes according to past feeding history}

Sea urchins in the Undaria-fed group showed a remarkably reduced consumption rate for their initially most preferred $U$. pinnatifida compared to the starved group (Tukey's post hoc test, $\mathrm{p}=0.024$ ) due to the influence of past feeding history (Table 1, Fig. 1). A similar pattern was found for another brown alga, S. confusum (Tukey's post hoc test, $\mathrm{p}=0.038$ ). In particular, unlike the starved group, sea urchins in the Undaria-fed group chose G. elliptica as the most preferred food $\left(2.06 \mathrm{~g} \mathrm{~d}^{-1}\right)$ (Fig. 1), leaving $U$. pinnatifida $\left(0.04 \mathrm{~g} \mathrm{~d}^{-1}\right)$ and S. confusum $\left(0.47 \mathrm{~g} \mathrm{~d}^{-1}\right)$ as the least preferred ones among the six food species. Consumption rates for the other three algae (U. australis, D. divaricata, and G. angusta) were very low, similar to those in the starved group. Consequently, all species except G. elliptica were barely consumed by sea urchins in the Undaria-fed group.

The Undaria-fed group showed a different preference according to the time elapsed after the initial feeding of

Table 1. Effects of past feeding history on actual consumption rate per day per individual between starved group and Undaria-fed group in Experiments 1 and 2

\begin{tabular}{lrrrc}
\hline \multicolumn{1}{c}{ Source } & df & \multicolumn{1}{c}{ MS } & \multicolumn{1}{c}{ F } & p-value \\
\hline Algae & 5 & 4.683 & 9.860 & 0.000 \\
Feeding & 1 & 11.052 & 12.270 & 0.000 \\
Feeding $\times$ Algae & 10 & 3.557 & 7.480 & 0.000 \\
Error & 126 & 0.475 & - & - \\
\hline
\end{tabular}

Table 2. Repeated measures ANOVA on consumption rate at early and later periods for the Undaria-fed group in Experiment 2

\begin{tabular}{lrrrc}
\hline \multicolumn{1}{c}{ Source } & df & MS & F & p-value \\
\hline Between subjects & & & & \\
$\quad$ Algae & 5 & 1.484 & 12.736 & 0.002 \\
$\quad$ Error & 24 & 0.273 & 5.441 & 0.002 \\
$\quad$ Within subjects & & & & \\
$\quad$ Period & 1 & 0.002 & 2.707 & 0.924 \\
Period $\times$ Algae & 5 & 0.630 & 0.009 & 0.045 \\
$\quad$ Error & 24 & 0.233 & - & - \\
\hline
\end{tabular}



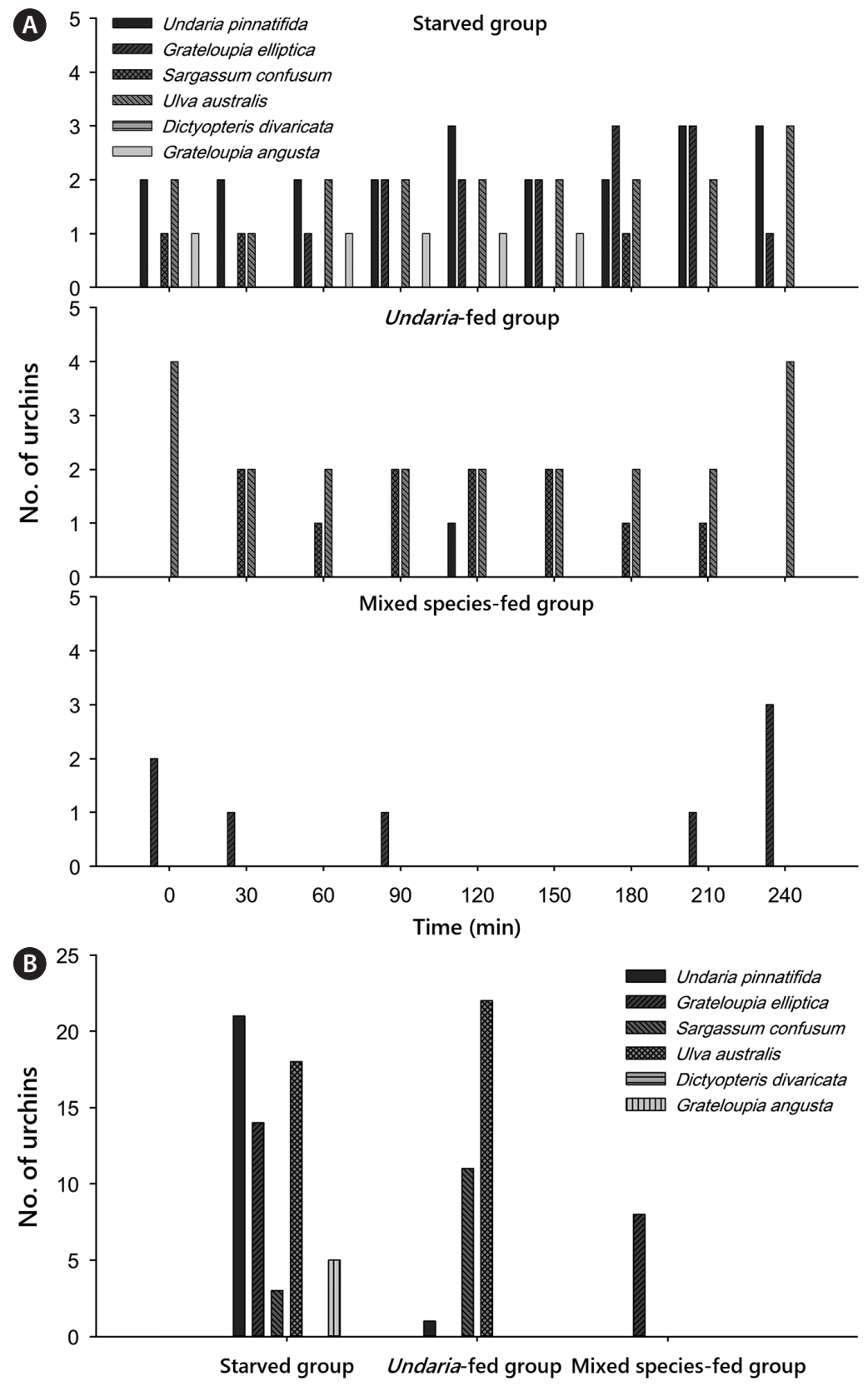

Fig. 4. Behavioral choice of Mesocentrotus nudus from the 3 groups—starved, Undaria-fed, and mixed species-fed-during 240 min in Experiment 3. Data are the number of urchins touching algal thallus at each observation point of every $30 \mathrm{~min}(\mathrm{~A})$ and accumulated number of urchins for $240 \min (B)$.

Undaria. In the early six days, G. elliptica $\left(0.61 \mathrm{~g} \mathrm{~d}^{-1}\right)$ and S. confusum $\left(0.56 \mathrm{~g} \mathrm{~d}^{-1}\right)$ were almost equally preferred. However, in the later six days, only G. elliptica $(1.43 \mathrm{~g}$ $\mathrm{d}^{-1}$ ) was exclusively preferred (Period $\times$ Algae, $\left.\mathrm{p}=0.045\right)$ (Table 2, Fig. 3). Particularly, the consumption rate of $U$. pinnatifida remained very low (at a rate similar to that of the least preferred group: $U$. australis, D. divaricata, $G$. angusta) for 12 days of the experimental period (Fig. 3).

\section{Behavioral choice vs. actual consumptions un- der past feeding conditions}

The starved group showed the most complex behavioral pattern, while the mixed species-fed group showed the simplest and inactive pattern (Fig. 4). For the starved group, U. pinnatifida and U. australis were always attracted by 2-3 sea urchins at every observation point for 


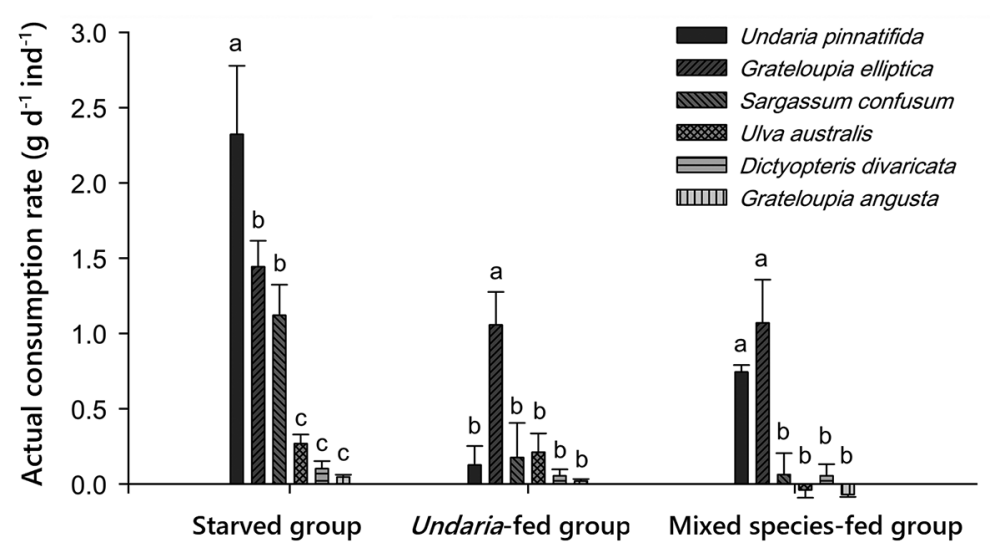

Fig. 5. Actual consumption rate of starved, Undaria-fed, and mixed species-fed group of Mesocentrotus nudus for 10 days during Experiment 3. Each bar indicates mean \pm standard error and the alphabets indicate different groups at $95 \%$ significance.

the entire period of $240 \mathrm{~min}$. However, G. elliptica was chosen by fewer urchins after $60 \mathrm{~min}$ passed since the first encounter. G. angusta and S. confusum were intermittently chosen by starved urchins, whereas $D$. divaricata was not chosen by sea urchins (Fig. 4). Behavioral choices of urchins for the Undaria-fed group were toward U. australis and S. confusum (Fig. 4). U. australis was always chosen by $2-4$ sea urchins of this group for $240 \mathrm{~min}$ and $S$. confusum was chosen by $1-2$ urchins for $180 \mathrm{~min}$. Not many sea urchins moved actively to chase food sources in the mixed species-fed group. Only G. elliptica was chosen intermittently by a few urchins for 240 $\min$ (Fig. 4).

Actual consumptions were not strictly matched with behavior patterns, in addition, preferred foods differed among the three groups (Table 3, Fig. 5). In the starved group, U. pinnatifida and G. elliptica were highly preferred both in behavioral choice and consumption. Although $U$. australis was highly attractive to urchins, it was consumed at a low rate (Fig. 5). Contrarily, S. confusum was eaten by starved urchins as much as G. elliptica, although it was ranked low in behavioral choice. Undar$i a$-fed urchins showed a complete mismatch in that $S$. confusum and $U$. australis were the most attractive species, but the least consumed foods. On the other hand,

Table 3. Effects of past feeding history on consumption of the starved group, the Undaria-fed group, and the mixed species-fed group in Experiment 3

\begin{tabular}{lrccc}
\hline \multicolumn{1}{c}{ Source } & df & MS & F & p-value \\
\hline Algae & 5 & 4.559 & 10.942 & 0.000 \\
Feeding & 2 & 6.494 & 15.586 & 0.000 \\
Feeding $\times$ Algae & 10 & 1.922 & 4.613 & 0.000 \\
Error & 126 & 0.417 & - & - \\
\hline
\end{tabular}

G. elliptica was the least attractive species, but the most consumed (Fig. 5). Sea urchins of this group fed only $G$. elliptica for 10 days and rarely consumed other algae. Although $U$. pinnatifida was not attractive to sea urchins of the mixed species-fed group, this alga was the most consumed food together with G. elliptica by this group (Fig. 5). Sea urchins of this group consumed only these two food species, while they rarely consumed the other four food species.

\section{DISCUSSION}

\section{Primary feeding preference}

Starved sea urchins in this study preferred Undaria pinnatifida. Preference for brown algae by the species of Strongylocentrotidae has been reported previously (Vadas 1977, Larson et al. 1980, Harrold and Reed 1985, Kim et al. 2007). In particular, Vadas (1977) has reported that feeding preferences of three Strogylocentrotidae sea urchins (M. franciscanus, Strongylocentrotus droebachiensis, and S. purpuratus) are toward large brown algae such as Nereocystis luetkeana, Saccharina latissima, and Costaria costata, emphasizing the intake efficiency rather than the calorie content of the food source (see also Larson et al. 1980). Earlier studies have described that a high absorption efficiency of strongylocentrotid sea urchins for kelp species is due to a high level of depolymerization of digestive enzymes to alginic acid and mannitol contained in brown algae (Eppley and Lasker 1959, Boolootian and Lasker 1964). Similarly, the large brown algae, $U$. pinnatifida and species of Sargassum have been reported to contain large amounts of alginic 
acid and mannitol (Zubia et al. 2008, Borines et al. 2013, Cho et al. 2013). Therefore, the high preference for the two large browns in our study consistently supports the importance of the intake efficiency for the food choice of M. nudus.

On the other hand, $D$. divaricata, another brown alga, showed a significantly lower consumption rate. It belonged to the least favorable group, unlike two other brown algae. Several species of Dictyopteris (e.g., D. justii and $D$. polypodioides) are known to have defensive chemicals such as sulfur compounds that can deter feeding by mesoherbivores such as amphipods and fishes (Hay et al. 1988, Schnitzler et al. 2001, Teixeira et al. 2006). Furthermore, Shiraishi et al. (1991) have reported that D. divaricata used in this study shows chemical defense against M. nudus using chromazonarol. Therefore, feeding patterns of herbivores regarding brown algae appear in a somewhat complex manner. U. pinnatifida or Sargassum spp. preferred by sea urchins in this study might have a chemical defense mechanism like common brown algae, but nutritionally more beneficial due to plenty of fucoxanthin (Terasaki et al. 2009, Fung et al. 2013). In addition, the susceptibility to defense chemicals could be variable depending on herbivore species, indicating the importance of pairwise specificity for defense action and preference of generalist herbivores prevailing in marine benthic systems (e.g., Rohde et al. 2004, Molis et al. 2006, 2008).

\section{Preference changes according to past feeding history and body size}

In the Undaria-fed group, the first choice of food was switched from U. pinnatifida to G. elliptica. This preference shift of sea urchins suggests that this herbivore can temporarily pursue nutritional balance by choosing less preferred food due to its strategic flexibility in feeding patterns (Pulliam 1975, Rapport 1980). For example, Lyons and Scheibling (2007) have reported that the green sea urchin, Strongylocentrotus droebachiensis, prefers to feed kelp species Saccharina latissima over the green alga Codium fragile. However, this preference can change depending on past feeding conditions (Lyons and Scheibling 2007). What specific chemical compounds or nutrients are responsible for such temporal changes in preference of sea urchins remain unknown. Exclusive preference to a specific food source (U. pinnatifida in our case) may give urchin a clear advantage such as somatic and gonadal growth, leading to increased fitness or reproductive success (Vadas 1977, Larson et al. 1980,
Lemire and Himmelman 1996). The preference change of the Undaria-fed group between early and later periods may provide a clear evidence that sea urchins can seek a different food temporally. The mechanical explanation for this preference change is unclear. It could be explained by beneficial improvement of performance with a mixed diet (Pennings et al. 1993, Cruz-Rivera and Hay 2001), supplement of insufficient nutrients (Rapport 1980), and avoiding excessive accumulation of conspecific prey's defensive chemicals (Freeland and Janzen 1974, Vadas 1977).

Large urchins showed a stronger preference for U. pinnatifida while small urchins equally preferred $U$. pinnatifida and G. elliptica in our study. We assume that this subtle distinction comes from different nutritional demands for small and large urchins toward growth and reproductive success, respectively. Kawakami et al. (1998) and Kelly and Symonds (2013) have reported that fucoxanthin and $\beta$-carotene from brown algae could be advantageous egg ovulation enhancement of sea urchins. $U$. pinnatifida is known to contain these compounds abundantly (Kolb et al. 2004, Fung et al. 2013). Thus, large $M$. nudus' increasing preference for $U$. pinnatifida could be related to a higher ovulation rate. On the other hand, Vadas (1977) and Larson et al. (1980) have reported that small urchins tend to choose foods advantageous for fast growing. A mixed diet may help the somatic growth of sea urchins (Scheibling and Anthony 2001, Seymour et al. 2013). These reports could explain why small urchins showed less biased preference than large urchins in our study. Therefore, preference change of sea urchins according to their body sizes might be directly related to an optimization strategy for enhancing fitness, leading to individual's performance or potential reproductive output (see Vadas 1977, Himmelman and Nédélec 1990, Lemire and Himmelman 1996).

\section{Foraging behavior by attractiveness vs. actual consumption}

In Experiment 3, sea urchins' foraging behavior by attractiveness of food species was largely consistent with their final consumption amounts, although they exhibited various exploratory approaches even to unpalatable foods at the beginning. These foraging behaviors also differed depending on dietary histories, indicating that urchins' food detecting responses were quite fast and sensitive. Interestingly, a few food species such as $U$. australis or G. angusta were chosen by sea urchins, although they were not consumed significantly. This may be explained 
by the fact that sea urchins can detect prey at a short distance by moving randomly and taste first and seek for another palatable prey if it is not. It has been reported that sea urchins S. droebachiensis and M. nudus generally move randomly or stochastically when they are foraging (Hayakawa and Kittaka 1984, Lauzon-Guay et al. 2006, Dumont et al. 2007). Dumont et al. (2007) have suggested that such random movement could be an appropriate behavior to enhance their chance to find food sources for sea urchins with limited perceptive ability. Likewise, sea urchins in this study seemed to move randomly at the first few hours. However, their final consumption amounts were largely coincident to their behavioral choice, indicating that this foraging behavior could be correlated with their actual consumption. Sea urchins' movement tends to be complex and random, but changeable depending on their dietary state in natural habitats such as barrens and algal beds. As shown partly in our indoor aquarium study, fully fed urchins in algal beds showed less active foraging movements. On the other hand, starved urchins in barrens showed more active and destructive grazing that might cause the barren state recycled (see Garnick 1978). This switching grazing modes of sea urchins might be one of key factors determining the community state where they inhabit as a part of a feedback mechanism (Filbee-Dexter and Scheibling 2014).

In summary, the primary feeding preference of sea urchin, $M$. nudus, was toward a brown alga $U$. pinnatifida. However, M. nudus showed preferential flexibility depending on their past feeding histories and body size. Additionally, their movement complexity toward food choice was strongly affected by past feeding histories. Our results indicate that $M$. nudus as a generalist herbivore can show plasticity and flexibility of feeding and foraging behaviors. This study provides experimental evidence of complex feeding patterns of a common sea urchin. It contributes to the feeding ecology of urchins and better understanding of mechanistic changes in macroalgal communities where urchin grazing is a major driving force.

\section{ACKNOWLEDGEMENTS}

Authors are very grateful to two anonymous reviewers for valuable and constructive comments on the earlier version of this manuscript. This study was supported by the NRF grant (2018R1D1A1B07048996) and FIRA grant (20150712) to JHK.

\section{CONFLICTS OF INTEREST}

The authors declare that they have no potential conflicts of interest.

\section{REFERENCES}

Agatsuma, Y. 2001. Ecology of Strongylocentrotus nudus. Dev. Aquac. Fish. Sci. 32:347-362.

Agnetta, D., Bonaviri, C., Badalamenti, F., Scianna, C., Vizzini, S. \& Gianguzza, P. 2013. Functional traits of two cooccurring sea urchins across a barren/forest patch system. J. Sea Res. 76:170-177.

Boolootian, R. A. \& Lasker, R. 1964. Digestion of brown algae and the distribution of nutrients in the purple sea urchin Strongylocentrotus purpuratus. Comp. Biochem. Physiol. 11:273-289.

Borines, M. G., de Leon, R. L. \& Cuello, J. L. 2013. Bioethanol production from the macroalgae Sargassum spp. Bioresour. Technol. 138:22-29.

Burkepile, D. E. \& Hay, M. E. 2006. Herbivore vs. nutrient control of marine primary producers: context-dependent effects. Ecology 87:3128-3139.

Chang, Y., Wang, Z. \& Wang, G. 1999. Effect of temperature and algae on feeding and growth in sea urchin Strongylocentrotus intermedius. J. Fish. China 23:69-76.

Cho, Y., Kim, H. \& Kim, S. -K. 2013. Bioethanol production from brown seaweed, Undaria pinnatifida, using $\mathrm{NaCl}$ acclimated yeast. Bioprocess Biosyst. Eng. 36:713-719.

Cruz-Rivera, E. \& Hay, M. E. 2001. Macroalgal traits and the feeding and fitness of an herbivorous amphipod: the roles of selectivity, mixing, and compensation. Mar. Ecol. Prog. Ser. 218:249-266.

Dayton, P. K., Tegner, M. J., Parnell, P. E. \& Edwards, P. B. 1992. Temporal and spatial patterns of disturbance and recovery in a kelp forest community. Ecol. Monogr. 62:421-445.

Dumont, C. P., Himmelman, J. H. \& Robinson, S. M. C. 2007. Random movement pattern of the sea urchin Strongylocentrotus droebachiensis. J. Exp. Mar. Biol. Ecol. 340:80-89.

Elner, R. W. \& Vadas, R. L. Sr. 1990. Inference in ecology: the sea urchin phenomenon in the northwestern Atlantic. Am. Nat. 136:108-125.

Eppley, R. W. \& Lasker, R. 1959. Alginase in the sea urchin Strongylocentrotus purpuratus. Science 129:214-215.

Filbee-Dexter, K. \& Scheibling, R. E. 2014. Sea urchin barrens as alternative stable states of collapsed kelp ecosystems. Mar. Ecol. Prog. Ser. 495:1-25. 
Filbee-Dexter, K. \& Scheibling, R. E. 2017. The present is the key to the past: linking regime shifts in kelp beds to the distribution of deep-living sea urchins. Ecology 98:253-264.

Freeland, W. J. \& Janzen, D. H. 1974. Strategies in herbivory by mammals: the role of plant secondary compounds. Am. Nat. 108:269-289.

Fung, A., Hamid, N. \& Lu, J. 2013. Fucoxanthin content and antioxidant properties of Undaria pinnatifida. Food Chem. 136:1055-1062.

Garnick, E. 1978. Behavioral ecology of Strongylocentrotus droebachiensis (Muller) (Echinodermata: Echinoidea): aggregating behavior and chemotaxis. Oecologia 37:77-84.

Harrold, C. \& Reed, D. C. 1985. Food availability, sea urchin grazing, and kelp forest community structure. Ecology 66:1160-1169.

Hay, M. E., Duffy, J. E., Fenical, W. \& Gustafson, K. 1988. Chemical defense in the seaweed Dictyopteris delicatula: differential effects against reef fishes and amphipods. Mar. Ecol. Prog. Ser. 48:185-192.

Hayakawa, Y. \& Kittaka, J. 1984. Simulation of feedig behavior of sea urchin Strongylocentrotus nudus. Bull. Jpn. Soc. Sci. Fish. 50:233-240.

Hernández, M., Bückle, F., Guisado, C., Barón, B. \& Estavillo, N. 2004. Critical thermal maximum and osmotic pressure of the red sea urchin Strongylocentrotus franciscanus acclimated at different temperatures. J. Therm. Biol. 29:231-236.

Hillebrand, H. \& Cardinale, B. J. 2004. Consumer effects decline with prey diversity. Ecol. Lett. 7:192-201.

Himmelman, J. H. \& Nédélec, H. 1990. Urchin foraging and algal survival strategies in intensely grazed communities in eastern Canada. Can. J. Fish. Aquat. Sci. 47:1011-1026.

Huntly, N. 1991. Herbivores and the dynamics of communities and ecosystems. Annu. Rev. Ecol. Syst. 22:477-503.

James, P. \& Siikavuopio, S. I. 2012. The effect of continuous and intermittent feeding regimes on survival and somatic and gonadal growths of the sea urchin, Strongylocentrotus droebachiensis. Aquaculture 364-365:173-179.

Jormalainen, V., Honkanen, T. \& Vesakoski, O. 2008. Geographical divergence in host use ability of a marine herbivore in alga-grazer interaction. Evol. Ecol. 22:545-559.

Kawakami, T., Tsushima, M., Katabami, Y., Mine, M., Ishida, A. \& Matsuno, T. 1998. Effect of $\beta, \beta$-carotene, $\beta$-echinenone, astaxanthin, fucoxanthin, vitamin A and vitamin $\mathrm{E}$ on the biological defense of the sea urchin Pseudocentrotus depressus. J. Exp. Mar. Biol. Ecol. 226:165-174.
Kawamata, S. 1997. Modelling the feeding rate of the sea urchin Strongylocentrotus nudus (A. Agassiz) on kelp. J. Exp. Mar. Biol. Ecol. 210:107-127.

Kelly, M. S. \& Symonds, R. C. 2013. Carotenoids in sea urchins. In Lawrence, J. M. (Ed.) Sea Urchins: Biology and Ecology. 3rd ed. Academic Press Inc., London, pp. 171-178.

Kim, C., Kim, Y. S., Choi, H. G. \& Nam, K. W. 2014. Variations of seaweed community structure and distribution of crustose coralline algae at Gallam, Samchuk, eastern coast of Korea. Korean J. Environ. Ecol. 28:10-23.

Kim, S. -K., Kim, Y. -D., Jeon, C. -Y., Gong, Y. -G., Kim, D. -S., Kim, J. -H., Kim, M. -L. \& Han, H. -K. 2007. Algal consumption and preference of sea urchins, Strongylocentrotus nudus, S. intermedius and abalone, Haliotis discus hannai. J. Korean Fish. Soc. 40:133-140.

Kolb, N., Vallorani, L., Milanović, N. \& Stocchi, V. 2004. Evaluation of marine algae wakame (Undaria pinnatifida) and kombu (Laminaria digitata japonica) as food supplements. Food Technol. Biotechnol. 42:57-61.

Krumhansl, K. A., Okamoto, D. K., Rassweiler, A., Novak, M., Bolton, J. J., Cavanaugh, K. C., Connell, S. D., Johnson, C. R., Konar, B., Ling, S. D., Micheli, F., Norderhaug, K. M., Pérez-Matus, A., Sousa-Pinto, I., Reed, D. C., Salomon, A. K., Shears, N. T., Wernberg, T., Anderson, R. J., Barrett, N. S., Buschmann, A. H., Carr, M. H., Caselle, J. E., Derrien-Courtel, S., Edgar, G. J., Edwards, M., Estes, J. A., Goodwin, C., Kenner, M. C., Kushner, D. J., Moy, F. E., Nunn, J., Steneck, R. S., Vásquez, J., Watson, J., Witman, J. D. \& Byrnes, J. E. K. 2016. Global patterns of kelp forest change over the past half-century. Proc. Natl. Acad. Sci. U. S. A. 113:13785-13790.

Larson, B. R., Vadas, R. L. \& Keser, M. 1980. Feeding and nutritional ecology of the sea urchin Strongylocentrotus drobachiensis in Maine, USA. Mar. Biol. 59:49-62.

Lauzon-Guay, J. -S. \& Scheibling, R. E. 2008. Evaluation of passive integrated transponder (PIT) tags in studies of sea urchins: caution advised. Aquat. Biol. 2:105-112.

Lauzon-Guay, J. -S., Scheibling, R. E. \& Barbeau, M. A. 2006. Movement patterns in the green sea urchin, Strongylocentrotus droebachiensis. J. Mar. Biol. Assoc. U. K. 86:167-174.

Lemire, M. \& Himmelman, J. H. 1996. Relation of food preference to fitness for the green sea urchin, Strongylocentrotus droebachiensis. Mar. Biol. 127:73-78.

Lyons, D. A. \& Scheibling, R. E. 2007. Effect of dietary history and algal traits on feeding rate and food preference in the green sea urchin Strongylocentrotus droebachiensis. J. Exp. Mar. Biol. Ecol. 349:194-204.

Machiguchi, Y., Mizutori, S. \& Sanbonsuga, Y. 1994. Food 
preference of sea urchin Strogylocentrotus nudus in laboratory. Bull. Hokkaido Natl. Fish. Res. Inst. 58:35-43.

Mann, K. H., Wright, J. L. C., Welsford, B. E. \& Hatfield, E. 1984. Responses of the sea urchin Strongylocentrotus droebachiensis (O.F. Müller) to water-borne stimuli from potential predators and potential food algae. J. Exp. Mar. Biol. Ecol. 79:233-244.

Molis, M., Körner, J., Ko, Y. W. \& Kim, J. H. 2008. Specificity of inducible seaweed anti-herbivory defences depends on identity of macroalgae and herbivores. Mar. Ecol. Prog. Ser. 354:97-105.

Molis, M., Körner, J., Ko, Y. W., Kim, J. H. \& Wahl, M. 2006. Inducible responses in the brown seaweed Ecklonia cava: the role of grazer identity and season. J. Ecol. 94:243-249.

Paine, R. T. \& Vadas, R. L. 1969. The effects of grazing by sea urchins Strongylocentrotus spp., on benthic algal populations. Limnol. Oceanogr. 14:710-719.

Palacín, C., Giribet, G., Carner, S., Dantart, L. \& Turon, X. 1998. Low densities of sea urchins influence the structure of algal assemblages in the western Mediterranean. J. Sea Res. 39:281-290.

Pearse, J. S. 2006. Ecological role of purple sea urchins. Science 314:940-941.

Pennings, S. C., Nadeau, M. T. \& Paul, V. J. 1993. Selectivity and growth of the generalist herbivore Dolabella auricularia feeding upon complementary resources. Ecology 74:879-890.

Pulliam, H. R. 1975. Diet optimization with nutrient constraints. Am. Nat. 109:765-768.

Rapport, D. J. 1980. Optimal foraging for complementary resources. Am. Nat. 116:324-346.

Rohde, S., Molis, M. \&Wahl, M. 2004. Regulation of anti-herbivore defence by Fucus vesiculosus in response to various cues. J. Ecol. 92:1011-1018.

Scheibling, R. \& Anthony, S. 2001. Feeding, growth and reproduction of sea urchins (Strongylocentrotus droebachiensis) on single and mixed diets of kelp (Laminaria spp.) and the invasive alga Codium fragile ssp. tomentosoides. Mar. Biol. 139:139-146.

Schnitzler, I., Pohnert, G., Hay, M. \& Boland, W. 2001. Chemical defense of brown algae (Dictyopteris spp.) against the herbivorous amphipod Ampithoe longimana. Oecologia 126:515-521.

Seymour, S., Paul, N. A., Dworjanyn, S. A. \& de Nys, R. 2013. Feeding preference and performance in the tropical sea urchin Tripneustes gratilla. Aquaculture 400-401:6-13.
Shin, J. D., Ahn, J. K., Kim, Y. H., Lee, S. B., Kim, J. H. \& Chung, I. K. 2008. Community structure of benthic marine algae at Daejin and Jukbyeon on the mid-east coast of Korea. Algae 23:231-240.

Shiraishi, K., Taniguchi, K., Kurata, K. \& Suzuki, M. 1991. Effects of the methanol extracts from the brown alga Dictyopteris divaricata on feeding by the sea urchin Strongylocentrotus nudus and the abalone Haliotis discus hannai. Nippon Suisan Gakkaishi 57:1945-1948.

Sohn, C. H., Choi, C. G. \& Kim, H. G. 2007. Algal communities and useful seaweed distribution at Gangnung and it's vicinity in east coast of Korea. Algae 22:45-52.

Steneck, R. S. 2013. Sea urchins as drivers of shallow benthic marine community structure. In Lawrence, J. M. (Ed.) Sea Urchins: Biology and Ecology, 3rd ed. Academic Press Inc., London, pp. 195-212.

Teixeira, V. L., Barbosa, J. P., Rocha, F. D., Kaplan, M. A. C., Houghton, P. J. \& Pereira, R. C. 2006. Hydroperoxysterols from the Brazilian brown seaweeds Dictyopteris justii and Spatoglossum schroederi (Dictyotales): a defensive strategy against herbivory. Nat. Prod. Commun. 1:293-297.

Terasaki, M., Hirose, A., Narayan, B., Baba, Y., Kawagoe, C., Yasui, H., Saga, N., Hosokawa, M. \& Miyashita, K. 2009. Evaluation of recoverable finctional lipid components of several brown seaweeds (Phaeophyta) from Japan with special reference to fucoxanthin and fucosterol contents. J. Phycol. 45:974-980.

Vadas, R. L. 1977. Preferential feeding: an optimization strategy in sea urchins. Ecol. Monogr. 47:337-371.

Westbrook, C. E., Ringang, R. R., Cantero, S. M. A. \& Toonen, R. J. 2015. Survivorship and feeding preferences among size classes of outplanted sea urchins,Tripneustes gratilla, and possible use as biocontrol for invasive alien algae. PeerJ 3:e1235.

Worm, B., Lotze, H. K., Hillebrand, H. \& Sommer, U. 2002. Consumer versus resource control of species diversity and ecosystem functioning. Nature 417:848-851.

Yurchenko, O. V. \& Reunov, A. A. 2004. Dimorphism of spermatozoa in the sea urchin Strongylocentrotus nudus. Russ. J. Mar. Biol. 30:354-357.

Zubia, M., Payri, C. \& Deslandes, E. 2008. Alginate, mannitol, phenolic compounds and biological activities of two range-extending brown algae, Sargassum mangarevense and Turbinaria ornata (Phaeophyta: Fucales), from Tahiti (French Polynesia). J. Appl. Phycol. 20:1033-1043. 